\section{The future of the $\mathbf{E U}$}

One of the most momentous events planned for the coming months is the referendum (scheduled for 23 June) that will decide whether the United Kingdom of Great Britain and Northern Ireland remains a member state of the European Union. Arduous negotiations in Brussels in late February, preceded by months of letter writing and personal visits to fellow heads of governments by British Prime Minister David Cameron, resulted in some kind of renegotiated membership treaty for the UK. The question is whether the new terms of membership suffice to counter widespread dissatisfaction with the EU and its workings. The matter is felt to be of such importance that the decision on whether to accept the new terms and remain a member, or whether to reject them and leave, will not be taken by the elected representatives (Members of Parliament) but will be put before the entire voting population in a referendum. ${ }^{1}$ In terms of economic and political significance, it could be compared with a referendum of Californians on whether to leave the federation of the USA. Undoubtedly the entire world will be interested in the outcome. On what basis will the individual decision how to vote be made?

Many people have already voiced an opinion on the matter. Some of these people have commanded broadcasting time or newspaper columns and their opinions have been received by thousands or even millions of people, others have merely been heard by those surrounding them in a bar. In most cases some justification for the opinion is given. Even if one is resolved to consider the matter from the most basic level possible, one is hearing and reading these opinions and purported reasons of others, and they may also be taken into account.

Knowledge of any vested interest of an opiniongiver will doubtless temper the seriousness with which the opinion can be received. Companies whose business is mainly exporting to or importing from the EU, or translating official documents emanating from the European Commission; farmers receiving subsidies from the Common Agricultural Policy; or indeed any organization receiving subsidies from an organ of the EU, are all likely to be in favour of remaining a member. That is not to say that their opinion is wrong, merely that it should not be given undue weight (conversely, the contrary opinion expressed by such bodies accrues extra weight, although it might appear that they were unprincipled in accepting subsidies or engaging in such business). Perhaps the rule for appraising the weight or validity of any opinion should be firstly to attempt to predict from knowledge of the opinion-giver's situation what their view will be. If their stated opinion concurs with the prediction, then a small weight should be ascribed to it.

\section{The economic aspect}

The most vociferously debated aspect of the question seems to be the economic one. Many have issued dire warnings of economic catastrophe if the UK leaves; others have predicted the opposite. Such predictions may safely be made because their correctness can never be tested: the UK is not going to be divided into two equal halves, one of which will remain a member and the other one of which will leave (even that would not be a real test, because half the UK is obviously very different from the entire UK). A nation of sixty million active, intelligent people is not certainly going to sit around twiddling its thumbs. If the UK leaves, some opportunities will vanish and others will appear, with neither course appearing to be preponderant. Even if, upon changing the status quo, there was a distinct economic upturn or downturn, it might be hard to exclude some confounding factor. ${ }^{2}$

Many forecasts of the economic consequences of remaining in or leaving the EU have been made. Acrimonious exchanges regarding the transparency and validity of the models and the assumptions used in selecting their input parameters are being made. Most of these forecasts, presumably, use some kind of system dynamics, introduced by Jay Forrester and made famous by the Meadows et al. report The Limits to Growth. They suffer, therefore, from the limitation that unpredictable events are excluded. ${ }^{3}$ One can, therefore, give very little credence to the "results"often in the form of percentage income losses or gains given with at least one decimal place - of forecasts extending out to 2020, 2030 and beyond. It will doubtless have been noticed that the same forecasters generally

1 It should be noted that the renegotiated treaty still needs to pass some hurdles of approval, such as the European Parliament; hence, its implementation is not guaranteed.

2 Shortly after the National Health Service (NHS) was founded, Britain suffered a marked decline in life expectancy. Although no irrefutable explanation for this event has been given, a causative link to the NHS seems implausible.

3 See [1] for a detailed critique of models that fail to encompass real-world complexity. 
failed to predict the 2008 economic crisis. It is clear enough that there will be a fiscal gain upon leaving the EU-Britain is a net contributor to the EU budget. ${ }^{4}$

We have, therefore, to say that the economic aspect is not really quantifiable and should be neglected as a factor of importance. It does seem clear that there will be less bureaucracy upon leaving the EU. Dealing with regulations and form-filling actually contributes positively to gross domestic product (GDP), but if that is no longer necessary the time and energy presently spent on such matters will be freed up to devote to more innovative thinking and action. ${ }^{5}$

In any case, is this matter really to be decided on an economic argument? The predictions seem to range between not more than 10\% "better off" or "worse off". This seems to be well within the "noise" (uncertainty) of any prediction. Everyone can agree that the EU is no El Dorado (whatever might have been promised initially); similarly everyone can agree that Britain will not be reduced to indigence whether it leaves or whether it remains. Besides, it suffices to quote Aesop to recall that there is an eternal trade-off between "bread" and "freedom","6 the former generally has its price.

\section{Sovereignty}

Almost equally vociferously debated is the aspect of sovereignty. Undoubtedly, being part of a federation involves some loss of sovereignty. This is usually accepted as being part of a trade-off for economic and possibly cultural benefits. The former may include the assumption of a collective defence policy and military force. The question then is, what degree of loss is acceptable? There might be an irreducible set of core values, of "Englishness" or "Britishness", that cannot be encroached upon without destroying the essence of England or Britain. It is, in fact, a widely perceived impression that the ultimate goal of the EU is to reduce everyone to identical "units" indistinguishable from one another. The entire corpus of Eurospeak points to that goal; for example, cows are officially referred to as "grain-consuming units"; and it cannot be pretended that language is divorced from the underlying thought that produced it. ${ }^{7}$

In an illuminating Opinion on an appeal concerning the Anti-terrorism, Crime and Security Act 2001, Lord Hoffmann examined what is "the life of the nation", and pointed out that Britain, "more than any other [country] in the world, has an unbroken history of living for centuries under institutions and in accordance with values which show a recognisable continuity" [2], and went on to remark that "the real threat to the life of the nation, in the sense of a people living in accordance with its traditional laws and political values, comes ... from laws such as these." This Opinion could well be adapted to apply to the body of EU legislation.

A common set of core values has sometimes been put forward as a defining feature of EU membership. Politicians have opined that it is undesirable for Turkey to join the EU because it is an Islamic state, whereas all the other members of the EU are Christian states. It is doubtful whether the hard-core bureaucrats within the EU Commission (we use this term to designate an imagined body of men and women who play a preponderant rôle in shaping the development of the EU; possibly no such body exists but on the other hand concepts such as that of the "unit" citizen did not emerge spontaneously) would agree with this because the "unit" concept does not admit a religious dimension. The core value of the EU is lowest common denominatorism, of which the unit is the embodiment, and a Turkish unit can be as good a citizen as a German or Lithuanian unit. Besides, Christianity is in sharp decline in Europe and at the same time most countries have a significant minority of adherents of Islam.

Sober consideration of the EU's ineluctable march towards some kind of superstate (Article 1 of the Treaty of Lisbon: ${ }^{8}$ "This Treaty marks a new stage in

\footnotetext{
${ }^{4}$ Supporters of remaining within the EU generally assert that despite the net contribution, Britain gains more (e.g., in trade opportunities) from membership than it pays in. Such benefits are difficult to quantify, hence recourse is made to modeling. Admittedly a considerable proportion of the gross contribution to the budget is returned in the form of various grants and subsidies. This returning money is not, however, quite the same as what went out; it accrues a hedge, or sometimes even a forest, of restrictions and regulations.

5 It has been pointed out that a good deal of the present burden of bureaucratic regulations comes from Britain's own government. If this is true, then it is now a very timely moment to initiate a strong effort to diminish it - especially if the country is no longer shackled by the supranational Brussels bureaucracy, the presence of which otherwise makes the effort akin to that of Sisyphus.

6 A very plump dog met with a wolf who began to question him: Where was he fed that he had become such a big, fat dog? "A rich master feeds me," said the dog. "But what about your neck," asked the wolf, "why does it have a bare spot on it?" "My skin has been rubbed by the iron collar, which my keeper forged and put on me." The wolf laughed at him mockingly and said "Away with that kind of luxury! It's not for me at the cost of having my neck frayed with an iron collar." (No 100 in Babrius' collection of Aesopic fables).

7 Cf. Orwell's essay Politics and the English Language.

$8 \mathrm{Cm} 7310(2008)$.
} 
the process of creating an ever closer union among the peoples of Europe ...") can leave little doubt that it does indeed threaten the life of the nation in the sense expounded by Lord Hoffmann.

\section{Geography}

Geography has also been proposed as the basis of membership criteria, but cannot be taken very seriously. The country at the very heart of Europe geographically, namely Switzerland, is not a member. Conversely countries such as Spain and Portugal, which geographically belong more to Africa than to Europe, are among the most enthusiastic members. Being situated on the western margin of the continent, Britain cannot claim strong geographical links. Note that if Britain were to leave for geographical reasons, it would imply that Ireland should too.

Even in the present era of services deliverable via the Internet, geography still greatly influences trade patterns. Countries on the western seaboard of the continent, like Britain and Portugal, are more advantageously placed to trade with the entire world than, say, Germany, which is very well placed to trade with the bulk of the continental population. ${ }^{9}$ It is probably significant that Britain has a growing trade deficit with the rest of the EU; looking back over the last 15 years, imports from the EU have remained roughly constant but the proportion of exports has fallen from about $60 \%$ in 2000 to less than $50 \%$ last year.

\section{Migration}

Another vociferously debated aspect of the question is (im)migration. Britain is already a crowded island and infrastructural services such as health and transport can barely cope with demand, as measured, for example, by waiting times in the accident and emergency departments in hospitals, the proportion of standing passengers in trains, and the duration of traffic jams. A simplistic reckoning might suggest that a greater population will generate greater tax revenues, which could be spent on expanding infrastructural services. Such expansion is, however, very slow and may lag many years, if not decades, behind demand. We see this in the timescales for constructing new electricity generating stations and for building, or rebuilding formerly closed, railways. It might be that sometimes what is needed is not more spending but better organization. In that case, an influx of intelligent, entrepreneurial migrants might contribute to improvement. On the other hand it might not—organizations are generally controlled by officials in permanent posts whose ranks are unlikely to include recent immigrants. Furthermore, under EU rules, any citizen of another EU member state has the right to come to Britain, or any other EU country: no kind of merit-based selection process can be applied.

The ability to control immigration is put forward as an argument for leaving the EU. Nevertheless, in the pre-EU era immigration was not always managed wisely (e.g., the Commonwealth Immigration Act 1968). The fact is that Britain has a long history of immigration [3] ("long" is, of course, a relative term). The British Isles have experienced immigration for thousands of years, and past invasions of Romans, Danes, Normans and others have become an integral part of British civilization. Closer scrutiny of the matter suggests that it is not immigration per se that is undesirable, but the inability to control what is going on. "Control" might be illusory, and of course an invasion is uncontrolled, but the perception now is that policy is shackled by treaty obligations included in a very large package, so the issue really boils down to sovereignty.

\section{Science and innovation}

Readers of this journal may be particularly interested in the impact of the EU on their professional activities. This theme has been dealt with earlier [4] and the assessment has not been favourable. Although EU grants are generally welcomed by institutes in other EU member states, in Britain, perhaps because of more careful accounting procedures, they are not because in practice they need to be subsidized by the institute's own funds in order to fulfil the agreed programme. The facilitation of international collaboration (with scientists from other EU member states) has been given as an advantage of EU membership, but a survey of quantitative studies of international collaboration, carried out 10 years after the first "Framework" research and technical development programme was launched, concluded that "At least on the macro level, there is no evidence for the effect of [EU] commission policy. The UK science system appears to be moving along its own trajectory" [5]. More ominously, a special report of the European Court of Auditors on the European Institute of Innovation and Technology (EIT, with a budget of several milliard euros) highlights that

\footnotetext{
9 This can be easily seen by drawing circles of radius $1000 \mathrm{~km}$ — roughly corresponding to a day's journey overland — centred on the Ruhr valley and other great manufacturing centres, and counting the population included within the circle.
} 
Europe is lagging behind in innovation and concludes that it "must modify its delivery mechanisms and elements of its design to achieve the expected impact". ${ }^{10}$ Any dispassionate assessment of the whole panoply of science-oriented activities must conclude that it gives very poor value for money compared with what could be achieved, for example simply by giving the same money directly to the scientists.

\section{Ethics}

Finally, there is the ethical aspect of EU membership. If we admit that as the basis on which we must decide, the question then arises, what ethics? Utilitarianism - the greatest good of the greatest number? That would fit in with the lowest common denominatorism ethos, but despite the attention paid by the EU bureaucracy to quantifying activity using Quetelet-style social statistics, there has never been a concerted, comprehensive effort to apply the utilitarian (or indeed any other) criterion to the decision-making process. Policy is batted hither and thither by the influence of powerful lobbying groups and loses itself in a labyrinth of inanities. A tyranny can exist without the presence of a Stalin-like figure, and can be just as soul-destroying even if delocalized in an insidious web of bureaucratic regulation.

\section{The writing on the wall}

"MENE, MENE, TEKEL, UPHARSIN. This is the interpretation of the thing: MENE; God hath numbered thy kingdom, and finished it. TEKEL; Thou art weighed in the balances, and found wanting. PERES ; thy kingdom is divided ...". ${ }^{11}$ Although EU officials and sundry supporters of that institution assume, in their pronouncements of dire warnings if Britain (or, indeed, any other present member state) leaves it, that it will continue unperturbed towards its ultimate goal, ${ }^{8}$ the reality is likely to be that the EU as a whole will be dealt a fatal blow on 23 June. This is likely to be so whatever the outcome, because the referendum has sparked an unprecedented activity of discussion and debate, calling every aspect of the EU into question, which is far from being confined to the UK. It has been estimated that between one third and one half of all individual citizens throughout the EU are, individually, opposed to it; this latent opposition may now be sufficiently encouraged to build up enough momentum to lead to a general breakup. It is the right of any member state to withdraw from the EU. ${ }^{12}$ Let us hope that the response of the central authorities in Brussels will not be the same as that which led to the death of 20 Georgians, mostly young women, when a large demonstration in favour of leaving the Soviet Union was attacked by the Soviet army on 9 April $1989 .{ }^{13}$

It seems unlikely that the breakup of the EU will be as abrupt as that of the CMEA (Comecon). For a while, the "upgrades" to the treaties will doubtless continue, each time becoming longer and more unwieldy. ${ }^{14}$ At the same time new directives and regulations will continue to be introduced. I was recently apprised of the fact that, as part of the general policy of harmonizing VAT rates, Britain (and Ireland) are likely to lose the zero rating of printed books: in accord with lowest common denominatorism, it is extremely unlikely that the harmonization will take the form of zero-rating books in all member states. This particular measure will, of course, be of particular concern to scientists and other academics - the symbolic value of the zero rating is even more important than the fiscal aspect. And already introduced (in 2013), but still little-known, is the requirement for natural stone products to be CEmarked. It is an interesting question whether such legislation would have prevented what now appears to have been stone of inadequate quality having been used in the construction of the present Houses of Parliament in London about 150 years ago.

A period of slow decline suggests that visitors to the EU from other parts of the world will end up making comments similar to those made by travelers to the Ottoman Empire in its final years: “... the rule of Turkey has afflicted the country [Palestine] with a kind of social and political malaria" and "... the country, sick unto death, has fallen into the baneful care of Turkey" [6]. I have not recently visited Germany and thus forbear to

\footnotetext{
${ }^{10}$ Document QJ-AB-16-003-EN from the Publications Office of the European Union (Luxembourg, 2016).

${ }^{11}$ Daniel 5, 25-28.

${ }^{12}$ Treaty of Lisbon, ${ }^{8}$ Article 50, ๆ 1: “Any Member State may decide to withdraw from the Union in accordance with its own constitutional requirements."

${ }^{13}$ Notwithstanding the provisions of the Treaty concerning the Establishment of the Union of Soviet Socialist Republics (30 December 1922), $₫ 26$ : "Each Allied Republic retains the right to leave the Union."

${ }^{14}$ This recalls the software "upgrades", of which Microsoft seems to be the leader in their importunate (usually inconvenient and intrusive) delivery. For example, from its Skype Internet telephone service: "We've updated Skype so you have the latest version - including performance improvements and general fixes." One might well ask why the fixes were necessary in the first place, but anyway the opinion of users suggests that performance is usually degraded rather than upgraded. The main problem is that the update simply adds yet more lines of code to an already very lengthy program, making it even more unwieldy and crash-prone.
} 
comment on its present state, but certainly the observation of "a kind of social and political malaria" would well describe most other Eurozone countries.

\section{Conclusion}

Ideally the result of the referendum will be the aggregate of many individual, independent decisions but in reality a smaller number of influential figures will doubtless make their decision publicly known, and many individuals will simply follow one of those decisions (to save them the bother of having to go into the matter themselves?). The comments in this editorial are especially directed to those preparing to make an independent decision about the matter.

J.J. RAMSDEN

\section{References}

1. P.M. Allen and M. Strathern, Complexity, stability and crises. In: Complexity and Security (eds J.J. Ramsden \& P.J. Kervalishvili), pp. 71-92. Amsterdam: IOS Press (2008).

2. House of Lords Session 2004-5 [2004] UKHL 56, especially pp. 91-97.

3. E.g., R. Hansen, Citizenship and Immigration in Postwar Britain. New York: Oxford University Press (2000).

4. J.J. Ramsden, Widespread dissatisfaction with European Union research funding. J. Biol. Phys. Chem. 10 (2010) 3-4.

5. J.S. Katz and D. Hicks, Questions of collaboration. Nature $375(1995) 99$.

6. F. Treves, The Land That Is Desolate. London: Smith, Elder \& Co. (1912). 